\title{
Rekayasa Simulator Penghancur Tablet dengan Kontrol Suhu \& Motor
}

\author{
Della Fitriana Nur Faizin*1, Wisnu Kartika ${ }^{2}$, Kuat Supriyadi ${ }^{3}$, Erika Loniza ${ }^{4}$, Meilia Safitri \\ Universitas Muhammadiyah Yogyakarta
}

\section{INFO ARTIKEL}

Alamat Web Artikel:

https://journal.umy.ac.id/index.php $/ \mathrm{mt} /$ article/view/11411

DOI:

https://doi.org/10.18196/mt.v2i2.11411

Data Artikel:

Diterima:

01 Februari 2021

Direview:

15 Februari 2021

Direvisi :

08 Maret 2021

Disetujui :

31 Maret 2021

\section{Korespondensi:}

della.fitriana.d317@mail.umy.ac.id

\begin{abstract}
ABSTRAK
Dalam menentukan kualitas suatu tablet diperlukan 4 pengujian yaitu uji keseragaman ukuran, uji kekerasan, uji keregasan, uji waktu hancur (desintegration tester) dan penetapan kadar. Desintegration Tester adalah alat pengujian yang digunakan pada industri farmasi untuk mengetahui berapa lama waktu hancur obat. Proses uji waktu hancur tablet biasanya dilakukan secara manual dengan cara tablet dicelupkan kedalam air hangat selama beberapa waktu sesuai dengan bentuk tablet yang diuji, untuk pengujian seperti itu akan membutuhkan waktu dan tidak efisien. Dari acuan diatas maka penulis membuat perancangan desintegration tester dengan system kerja yaitu lengan penampang tablet digerakan dengan motor power window, dan tampilan suhu air didalam chamber yang dapat dipantau. Penelitian ini menggunakan sensor suhu ds18b20 dan dikendalikan oleh mikrokontroler ATMega328. Suhu $37^{\circ} \mathrm{C}$ akan ditampilkan pada LCD karakter $2 \times 16$ dalam proses berjalannya uji waktu hancur obat. Lengan penampang obat akan digerakan oleh motor power window. Hasil pengukuran suhu diperoleh nilai error sebesar $0,013 \%$ dan nilai error motor power window sebesar $0,39 \%$.
\end{abstract}

Kata Kunci : Desintegration Tester, Suhu, Ds18b20, Motor Power Window

\begin{abstract}
In determining the quality of a tablet, the uniformity of size test, hardness test, firmness test, desintegration tester, and assay were carried out. Desintegration Tester is a tool used in the pharmaceutical industry to determine how long it takes to destroy drugs. The process of testing the tablet desintegration time is usually done manually by dipping the tablet in warm water for some time according to the form of the tablet, and such testing usually takes time and inefficient. From the reference, the authors make a desintegration tester design with the tablet cross-section arm moved by a motor power window and a display of water temperature in the chamber that can be monitored. This study uses a temperature sensor ds $18 b 20$ and is controlled by an ATMega328 microcontroller. A temperature of $37^{\circ} \mathrm{C}$ will be displayed on the $2 x 16$ character $L C D$ in the process of running the drug breakdown time test. The temperature measurement results obtained an error value of $0.013 \%$ and an error value of the motor power window of $0.39 \%$.
\end{abstract}

Keywords: Disintegration Tester, Temperature, Ds18b20, Power Window Motor

\section{PENDAHULUAN}

Perkembangan dan kemajuan sarana dan alat-alat kesehatan saat ini telah berkembang pesat. Instrumen medis mengalami peningkatan mutu disebabkan karena perkembangan ilmu pengetahuan dan teknologi yang sangat signifikan grafik peningkatannya, hingga tersebar mengimbangi kemajuan IPTEK [1]. Instrumen medis biasanya menggunakan mikroprosesor maupun mikrokontroler yang dapat digunakan untuk menjalankan peralatan medis [2]. Arduino merupakan salah satu jenis mikrokontroler yang saat ini telah banyak digunakan pada penelitian [3]. Penggunaan Arduino saat ini telah banyak digunakan pada pengembangan peralatan medis [4]. Obat merupakan salah satu aspek penting dalam upaya penyelenggaraan kesehatan [5][6]. Obat memiliki berbagai macam bentuk salah satunya tablet. Tablet adalah sediaan padat yang mengandung bahan obat dengan atau tanpa bahan pengisi[7]. 


\section{Faizin, Kartika, Supriyadi}

Rekayasa Simulator Penghancur Tablet Dengan Kontrol Suhu \& Motor

Salah satu metode pengujian yang dilakukan dalam pembuatan tablet adalah dengan cara melakukan uji waktu hancur. Waktu hancur tablet juga menggambarkan cepat lambatnya tablet hancur dalam cairan pencernaan [7]. Di bidang farmasi suatu pengujian tablet, salah satunya pengujian waktu hancur tablet. Alat uji waktu hancur tablet yaitu desintegration tester yang berfungsi sebagai tes kelayakan fisik tablet sesuai dengan prosedur yang telah ditentukan, yaitu mengukur waktu hancur tablet sebelum dikonsumsi oleh pasien[8][9].

Pengujian waktu hancur tablet dilakukan dengan cara meletakkan tablet di atas kasa yang tahan karat, kemudian dimasukkan dalam air dengan suhu $37^{\circ} \mathrm{C}$, suhu dipantau menggunakan thermometer dan dinaik turunkan keranjang selama kurang lebih 20 kali dalam satu menit.

Berdasarkan acuan diatas, diperlukan sebuah sistem yang dapat menghancurkan tablet secara otomatis, oleh karena itu penulis akan membuat rekayasa alat simulator uji penghancur tablet dengan kontrol suhu dan motor yang bertujuan agar user lebih mudah dalam melakukan uji waktu hancur tablet, dan mengecek kelarutan obat sebelum di pasarkan. Motor yang digunakan untuk menggerakan lengan mekanik dengan menggunakan motor power window yang dikontrol oleh Mikrokontroler dan suhu yang digunakan yaitu sebesar $37^{\circ} \mathrm{C}$ yang ditampilkan di LCD tanpa harus memantau secara manual menggunakan termometer.

\section{METODE PENELITIAN}

Gambar 1 berikut merupakan Diagram kerangka kerja dalam proses pengerjaan alat tugas akhir penghancur tablet.

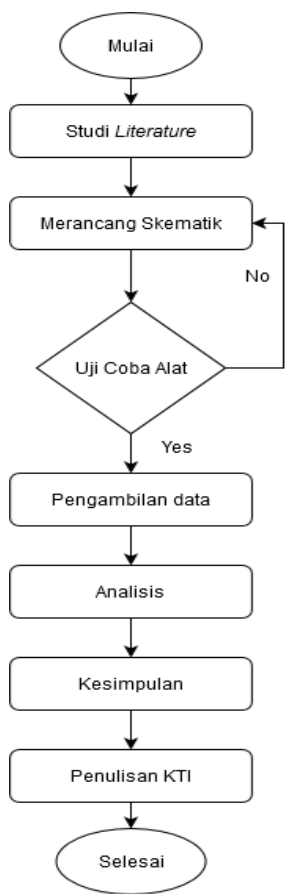

Gambar 1. Diagram System Perancangan

a. Studi Literature

Studi literature dilakukan dengan cara mendapatkan data dengan membaca buku, jurnal dan artikel-artikel yang memiliki keterkaitan dengan masalah pada tugas akhir ini.

b. Perancangan Skematik

Perancangan skematik yaitu mencari optimalisasi bentuk dari sistem yang akan dibuat dengan mempertimbangkan berbagai faktor kebutuhan dan permasalahan yang telah ditentukan.

c. Uji Coba Alat

Bertujuan untuk melakukan pengukuran dan pengujian alat penghancur tablet untuk melihat performa dari alat yang dirancang apakah alat telah berfungsi dengan baik. 


\section{Faizin, Kartika, Supriyadi}

Rekayasa Simulator Penghancur Tablet Dengan Kontrol Suhu \& Motor

d. Pengambilan Data

Proses ini dapat dilakukan jika alat yang telah dibuat dapat bekerja dengan baik dan sesuai dengan yang ditentukan.

e. Analisis dan Kesimpulan

Pengambilan kesimpulan hasil analisis dari permasalahan yang terjadi.

f. Penulisan KTI (Karya Tulis Ilmiah)

Berhubungan dengan perancangan alat yang telah dibuat. Penulisan KTI berisi tentang latar belakang permasalahan alat, dasaran teori dalam perancangan alat, metode penelitian alat yang berisi diagram sistem, alat dan bahan, blok diagram, diagram mekanik, diagram alir alat. Penulisan KTI juga berisi hasil serta pembahasan selama melakukan pengujian alat dan penutup yang berisi kesimpulan dan saran sebagai acuan pengembangan alat.

\subsection{Diagram Proses kerja}

Pada gambar 2 merupakan diagram proses kerja pada alat.

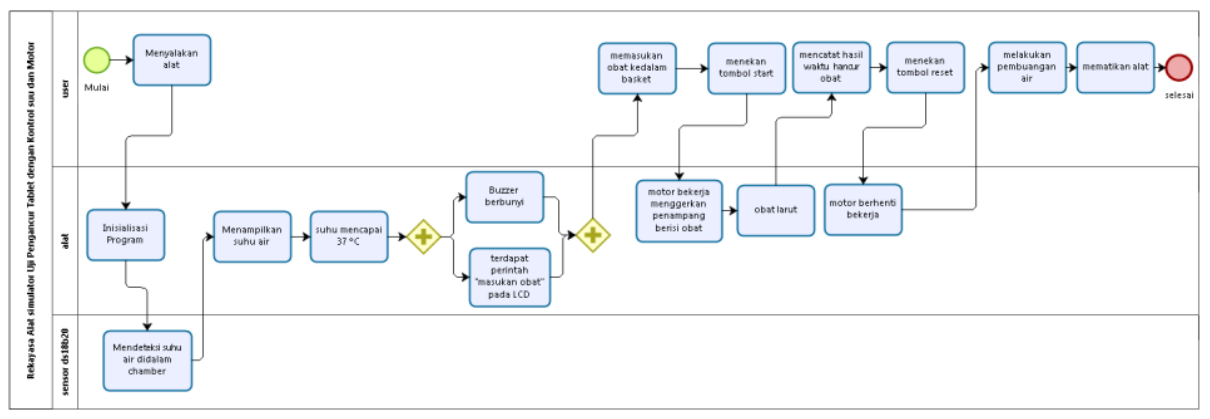

Gambar 2. Diagram Proses Kerja

Berdasarkan diagram alir pada gambar 2 dapat dijelaskan bahwa Saat saklar ON/OFF ditekan maka Mikrokontroler akan melakukan inisialisasi LCD untuk menampilkan waktu dan suhu, dilanjutkan heater bekerja untuk memanaskan air sampai suhu terjaga $37^{\circ} \mathrm{C}$. Buzzer akan berbunyi menandakan bahwa suhu telah mencapai $37^{\circ} \mathrm{C}$ maka user menekan tombol start, kemudian timer mulai menghitung sesuai yang telah ditentukan dan mikrokontroler bekerja menghidupkan motor power window yang menggerakkan keranjang obat untuk dicelupkan pada chamber. Setelah waktu habis dan proses selesai maka buzzer akan berbunyi dan motor berhenti bergerak. User dapat membuang air dengan cara menekan saklar pembuangan ketika proses pelarutan obat sudah selesai.

\subsection{Diagram Mekanis Sistem}

Perancanagan Desain alat dilakuakan menyesuaikan dengan hasil dari penentuan spesifikasi alat yang digunakan. Perencanaan desain alat pada gambar 3 yang akan dibuat diharapkan dapat berfungsi optimal.

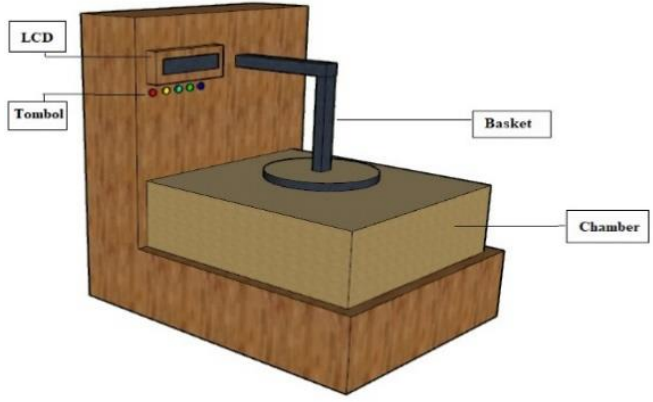

Gambar 3. Diagram Mekanis Sistem 
Faizin, Kartika, Supriyadi

Rekayasa Simulator Penghancur Tablet Dengan Kontrol Suhu \& Motor

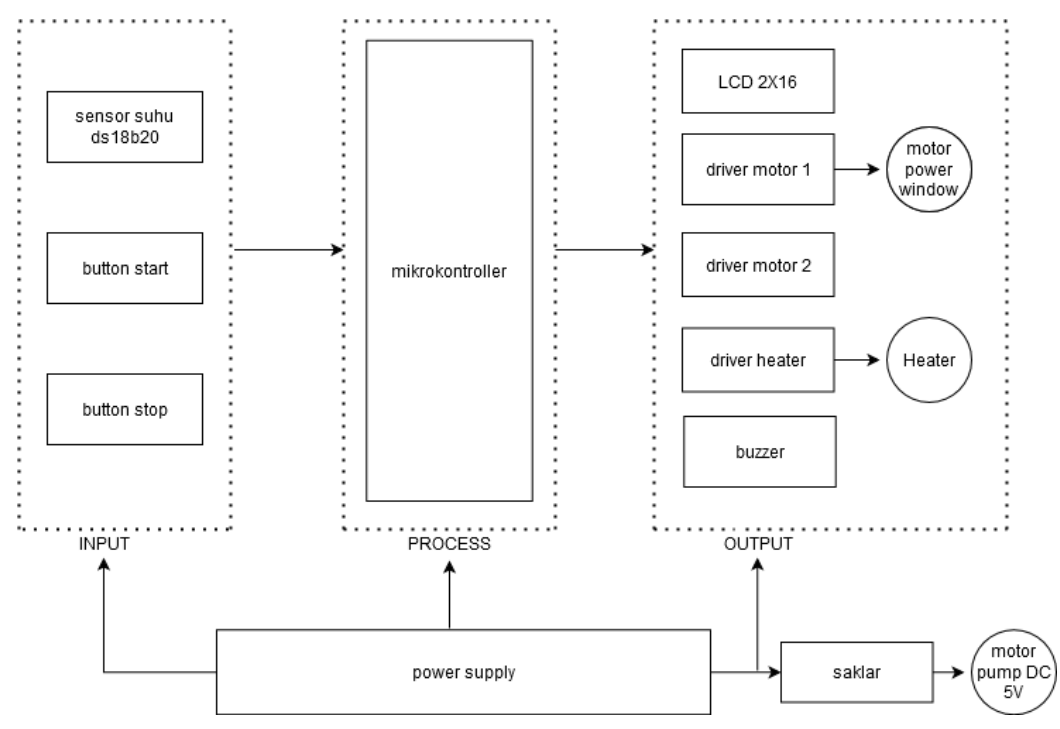

Gambar 4. Diagram Alir

Berdasarkan blok diagram pada Gambar 4 tegangan utama pada alat bersumber dari PLN sebesar 220 VAC. Tegangan PLN 220VAC masuk ke rangkaian power supply, yang berfungsi sebagai penyearah tegangan AC menjadi DC dan menurunkan tegangan PLN menjadi tegangan tertentu $(5 \mathrm{~V}$ dan $12 \mathrm{~V})$. Tegangan keluaran power supply $5 \mathrm{~V}$ memberikan sumber tegangan pada rangkaian mikrokontroler sebagai bagian pemroses sinyal perintah pada alat. Sinyal perintah terdiri dari beberapa bagian seperti push button dan sensor suhu. Mikrokontroler akan memproses sinyal perintah tersebut menjadi output berupa sinyal keluaran yang ditampilkan pada LCD, mengendalikan motor, menghidupkan heater, dan membunyikan buzzer. Mekanisme kerja alat bermula saat sensor suhu membaca suhu air didalam chamber, saat suhu belum mencapai $37^{\circ} \mathrm{C}$ maka heater akan bekerja memanaskan air didalam chamber hingga mencapai suhu $37^{\circ} \mathrm{C}$ setelah itu heater akan berhenti bekerja. Jika buzzer berbunyi yang menandakan bahwa suhu tela mencapai $37^{\circ} \mathrm{C}$ maka tekan tombol start, kemudian timer mulai menghitung sesuai yang telah ditentukan kemudian saat waktu belum habis maka mikrokontroller akan mengulangi terus menerus, apabila waktu habis maka mikrokontroler akan memerintahkan driver motor untuk berhenti bekerja kemudian sebagai penanda proses telah selesai maka mikrokontroler akan menyalakan buzzer, yang menandakan bahwa proses telah selesai.

\section{HASIL DAN PEMBAHASAN}

\subsection{Pengujian Sensor Suhu ds18b20}

Pengujian dilakukan dengan mengukur suhu air didalam chamber dengan menggunakan sensor suhu ds18b20 dengan pembanding thermometer. Data berikut diperoleh dari pengukuran sebanyak 15 kali pengukuran.

Tabel 1. Hasil uji kesesuaian modul TA dengan alat pembanding berupa thermometer didapatkan hasil pengukuran suhu sebanyak 15 kali dengan rata-rata yang dihasilkan pada modul TA sebesar $37,4^{\circ} \mathrm{C}$ dan pada alat pembanding sebesar $36,9^{\circ} \mathrm{C}$ dengan persentase error sebesar $0,013 \%$. Nilai yang dihasilkan tidak terpaut jauh dengan alat pembanding. Selisih antara thermometer dengan pembacaan suhu masih dalam batas toleransi. Adapun nilai error disebabkan oleh beberapa hal, antara lain: penempatan sensor suhu modul dengan sensor suhu alat pembanding terdapat sedikit jarak meskipun sudah saling didekatkan, gangguan perubahan suhu ketika proses sedang berlangsung. Suhu setting sebesar $37^{\circ} \mathrm{C}$ dikarenakan berdasar pada suhu tubuh manusia. Suhu berpengaruh pada kelarutan obat yang menyebabkan jarak antarmolekul zat padat menjadi renggang. Hal ini menyebabkan ikatan antarzat padat mudah terlepas oleh gaya tarik molekul-molekul air, sehingga zat pada obat tersebut mudah larut[10]. Semakin besar suhu air maka obat akan semakin cepat larut dan begitupun sebaliknya, semakin kecil suhu air maka obat akan semakin lama larut. 


\section{Faizin, Kartika, Supriyadi}

Rekayasa Simulator Penghancur Tablet Dengan Kontrol Suhu \& Motor

Obat sepenuhnya tersedia untuk diabsorsi dalam saluran cerna. Maka dari itu obat tablet juga harus memiliki kekerasan yang cukup yang sesuai dengan persyaratan yang ada, karena semakin kecil presentase kelarutan obat dari suatu tablet maka semakin baik efek terapi yang di berikan oleh tubuh.

Tabel 1. Data Pembacaan Sensor Suhu Ds18b20

\begin{tabular}{|c|c|c|}
\hline $\begin{array}{c}\text { Pengukuran } \\
\text { ke- }\end{array}$ & $\begin{array}{c}\text { Sensor } \\
\text { suhu } \\
\text { ds18b20 }\end{array}$ & Termometer \\
\hline 1 & $37^{\circ} \mathrm{C}$ & $37^{\circ} \mathrm{C}$ \\
\hline 2 & $37^{\circ} \mathrm{C}$ & $37^{\circ} \mathrm{C}$ \\
\hline 3 & $38^{\circ} \mathrm{C}$ & $37^{\circ} \mathrm{C}$ \\
\hline 4 & $38^{\circ} \mathrm{C}$ & $37^{\circ} \mathrm{C}$ \\
\hline 5 & $38^{\circ} \mathrm{C}$ & $37^{\circ} \mathrm{C}$ \\
\hline 6 & $38^{\circ} \mathrm{C}$ & $37^{\circ} \mathrm{C}$ \\
\hline 7 & $37^{\circ} \mathrm{C}$ & $37^{\circ} \mathrm{C}$ \\
\hline 8 & $37^{\circ} \mathrm{C}$ & $37^{\circ} \mathrm{C}$ \\
\hline 9 & $37^{\circ} \mathrm{C}$ & $36^{\circ} \mathrm{C}$ \\
\hline 10 & $37^{\circ} \mathrm{C}$ & $37^{\circ} \mathrm{C}$ \\
\hline 11 & $37^{\circ} \mathrm{C}$ & $37^{\circ} \mathrm{C}$ \\
\hline 12 & $38^{\circ} \mathrm{C}$ & $37^{\circ} \mathrm{C}$ \\
\hline 13 & $38^{\circ} \mathrm{C}$ & $37^{\circ} \mathrm{C}$ \\
\hline 14 & $37^{\circ} \mathrm{C}$ & $37^{\circ} \mathrm{C}$ \\
\hline 15 & $37^{\circ} \mathrm{C}$ & $37^{\circ} \mathrm{C}$ \\
\hline Rata-rata & $37,4^{\circ} \mathrm{C}$ & $36,9^{\circ} \mathrm{C}$ \\
\hline Error (\%) & \multicolumn{2}{|c|}{$0,013 \%$} \\
\hline
\end{tabular}

\subsection{Pengujian Output Motor Power Window}

Data berikut ini adalah data yang diperoleh dari nilai pengukuran pada alat dengan alat ukur Avometer digital dengan 10 kali pengukuran:

Tabel 2. Data Output Motor Power Window

\begin{tabular}{|c|c|c|}
\hline $\begin{array}{c}\text { Pengukuran } \\
\text { ke- }\end{array}$ & $\begin{array}{c}\text { Tegangan } \\
\text { supply Motor } \\
\text { dengan beban }\end{array}$ & $\begin{array}{c}\text { Tegangan } \\
\text { supply Motor } \\
\text { tanpa beban }\end{array}$ \\
\hline 1 & $3,0 \mathrm{~V}$ & $5 \mathrm{~V}$ \\
\hline 2 & $3,2 \mathrm{~V}$ & $5 \mathrm{~V}$ \\
\hline 3 & $3,0 \mathrm{~V}$ & $5 \mathrm{~V}$ \\
\hline 4 & $3,0 \mathrm{~V}$ & $5 \mathrm{~V}$ \\
\hline 5 & $2,9 \mathrm{~V}$ & $5 \mathrm{~V}$ \\
\hline 6 & $3,1 \mathrm{~V}$ & $5 \mathrm{~V}$ \\
\hline 7 & $2,9 \mathrm{~V}$ & $5 \mathrm{~V}$ \\
\hline 8 & $3,3 \mathrm{~V}$ & $5 \mathrm{~V}$ \\
\hline 9 & $2,9 \mathrm{~V}$ & $5 \mathrm{~V}$ \\
\hline 10 & $3,1 \mathrm{~V}$ & $5 \mathrm{~V}$ \\
\hline Rata-rata & $3,04 \mathrm{~V}$ & $5 \mathrm{~V}$ \\
\hline Error $(\%)$ & \multicolumn{2}{|c}{$0,39 \%$} \\
\hline
\end{tabular}


Tabel 2. diatas hasil dari pengukuran output motor power window didapatkan hasil pengukuran sebanyak 10 kali menggunakan avometer digital dengan rata-rata yang di hasilkan sebesar 3,04 V saat menggunakan beban motor power window dan dengan persentase error sebesar $0,39 \%$. Hasil rata-rata $5 \mathrm{~V}$ sebelum diberi beban motor power window. Nilai error yang terjadi dapat diakibatkan dari alat ukur yang kurang presisi dan mempunyai nilai toleransi yang cukup tinggi. Pada saat motor bekerja tegangan supply bernilai $3 \mathrm{~V}$ kemudian jika tanpa beban tegangan supply bernilai $5 \mathrm{~V}$ hal tersebut dikarenakan terdapat beban motor power window yang sedang bekerja sehingga tegangan supply pada saat motor bekerja menjadi 3V karena tegangan dikonsumsi oleh motor. Menggunakan inputan tegangan sebesar 5V karena menyesuaikan dengan standart pada Alat asli. Inputan tegangan $5 \mathrm{~V}$ pada motor power window dapat menggerakan lengan penampang yang berisi obat tablet secara naik turun sebanyak $25 \mathrm{kali}$. Hal ini sudah sesuai dengan alat uji waktu hancur tablet yang berada di Laboratorium Farmasi Universitas Muhammadiyah Yogyakarta.

\section{KESIMPULAN}

Berdasarkan hasil penelitian yang dilakukan dapat disimpulkan bahwa:

a. Kemungkinan tidak dapat memasang sensor yang dapat menggerakan keranjang yang berisi obat secara otomatis karena dibutuhkan waktu beberapa saat untuk user memasukan obat kedalam keranjang.

b. Pada pengujian suhu chamber didapatkan error $0,013 \%$ dan nilai ini masih dalam batas toleransi pengukuran.

c. Heater aquarium dengan merk amara kadang terjadi kendala saat digunakan karena kinerjanya kurang baik dalam memanaskan air.

d. Secara umum dapat disimpulkan bahwa modul dapat digunakan dengan baik sesuai fungsinya.

\section{DAFTAR PUSTAKA}

[1] A. Shinta, "friability tester," pp. 1-4, 2019.

[2] E. Loniza, H. Habiburrahman, and S. Ariwibowo, "Prototype Injeksi Insulin Pump Dengan Control Panel Arduino Uno," Med. Tek. J. Tek. Elektromedik Indones., vol. 1, no. 2, pp. 15, 2020, doi: 10.18196/mt.010206.

[3] H. R. Fajrin, U. Zakiyyah, and K. Supriyadi, "Alat Pengukur Ph Berbasis Arduino," Med. Tek. J. Tek. Elektromedik Indones., vol. 1, no. 2, 2020, doi: 10.18196/mt.010207.

[4] N. H. Wijaya, B. Untara, and I. Khoirunnisa, "Monitoring Tekanan Gas Medis Pada Instalasi Gas Medis Rumah Sakit," Med. Tek. J. Tek. Elektromedik Indones., vol. 1, no. 1, pp. 2-7, 2019, doi: 10.18196/mt.010104.

[5] D. A. Ade Maria Ulfa, Nofita, "Analisa Uji Kekerasan, Kerapuhan Dan Waktu Hancur Asam Mefenamat Kaplet Salut Generik Dan Merek Dagang,” vol. 1, no. 2, pp. 59-68, 2018.

[6] E. W. Ningsih, H. R. Fajrin, and A. Fitriyah, "Pendeteksi Hemoglobin Non Invasive," Med. Tek. J. Tek. Elektromedik Indones., vol. 1, no. 1, 2019, doi: 10.18196/mt.010102.

[7] M. Ahmad Faizin, Hj. Her Gumiwang Ariswati, ST, MT, Tri Bowo Indrato, ST, "disintegration tester," 2014.

[8] C. D. Yanti, K. Kesehatan, P. K. Surabaya, and J. T. Elektromedik, "Desintegration Tester Berbasis Mikrokontroler AT 89s52," pp. 1-79, 2011.

[9] M. Safitri, W. D. Iswara, and T. Harjono, "Blood Bag Shaker Dilengkapi Pemilihan Kecepatan Motor," Med. Tek. J. Tek. Elektromedik Indones., vol. 1, no. 2, 2020, doi: 10.18196/mt.010208.

[10] D. Joshinta, "Kestabilan obat," Dep. Farm. Univ. Indones., p. 16, 2008. 